9. Nyzhankovskyj O. (1908) Koncert v pamyat XLVII. rokovyn smerty T. Shevchenka u Lvovi [Concert in memory of XLVII. anniversary of Taras Shevchenko's death in Lviv]. Dyilo. Vyp. 60.17 marcya. P. 2; Vyp. 61.18 marcya. P. 2; Vyp. 62. 19 marcya. P. 4. [in Ukrainian].

10. Nyzhankovskyj O. (1902) Koncert «Stryjskogo Boyana»[Concert of «Stryisky Boyan»]. Dyilo. Vyp. 250. 6 (19) padolysta. P. 3. [in Ukrainian].

11. Nyzhankovskyj O. (1903) Lysenkove svyato v Kyyivi. Muzykalna chast vechera [Lysenkov holiday in Kiev. Musical part of the evening]. Dyilo. Vyp. 289. 24 grudnya (6 sichnya 1904). P. 2. [in Ukrainian].

12. Nyzhankovskyj O. (1902) Nasha Duma, ukrayinsko-ruski narodni pisnyi, zibrav i dlya horu ulozhyv Filyaret Kolesa [Our Duma, Ukrainian-Russian folk songs, collected and composed for the choir Filaret Kolesa]. Dyilo. Vyp. 63. 18 (31) marta. P. 3. [in Ukrainian].

13. O.N. (1895) V nedilyu (24 s. m.) predstavleno v teatri gr. Skarbka velyku operu Verdiogo «Traviata» [On Sunday (24 p.m.) presented at the theater gr. Treasure of Verdiogo's great opera «Traviata»]. Drolo. Vyp. 37. 16(28) lyutogo. P. 3. [in Ukrainian].

14. O.N. (1895) Manon Lescaut. Opera v 4 aktax Giacomo Puccini-ogo [Manon Lescaut. Opera in 4 acts by Giacomo Puccini]. Drolo. Vyp. 35. 14(26) lyutogo. P. 2. [in Ukrainian].

15. O.N. (1911) Markiyanove svyato u Lvovi [Markiyan's holiday in Lviv]. Dyilo. Vyp. 247. 6 padolysta (24 zhovtnya). P. 1-4. [in Ukrainian].

16. O.N. (1910) Ognyi Ivanovoyi nochi, drama Germana Sudermana [The Lights of St. John's Night, a drama by Hermann Suderman]. Dyilo. Vyp. 279. 14 grudnya. P. 6. [in Ukrainian].

17. O.N. (1895) Oratoriya Mechyslava Soltysa [Oratorio by Mieczyslaw Soltys]. Drolo. Vyp. 218.29 veresnya (11 zhovtnya). P. 3. [in Ukrainian].

18. O.N. (1894) I-ij koncert tovarystva spivaczkogo «Lyutnya» za 1894/5 rôku [The first concert of the «Lute» Singing Society in 1894/5]. Drolo. Vyp. 272 y 273.7 (19 grudnya). P. 4. [in Ukrainian].

19. Sovyak R. (2019) Ostap Nyzhankivskyj [Ostap Nyzhankivsky]. Stryj: «Shhedryk». 256 p. [in Ukrainian].

20. Romanyuk S. (2015) Afishi amatorskyh dramatychnyh gurtkiv Galychyny drugoyi polovyny XIX - pochatku XX st. (iz fondiv Insty`tutu doslidzhen bibliotechnyh mysteczkyh resursiv Lvivskoyi nacionalnoyi naukovoyi biblioteky Ukrayiny imeni V. Stefanyka) [Posters of amateur drama groups in Galicia in the second half of the XIX - early XX centuries. (from the funds of the Institute for Research of Library Art Resources of the V. Stefanyk Lviv National Scientific Library of Ukraine)]. P. 635-656. doi: http://www.lsl.lviv.ua/wp-content/uploads/Z/Z2015/JRN/PDF/43.pdf. [in Ukrainian].

21. Shutyak L. (2014). Osoblyvosti ukrayinskogo hudozhnogo reportazhu v konteksti «novogo zhurnalizmu» [Features of Ukrainian fiction reporting in the context of «new journalism»]. Derzhava ta regiony. Seriya: Socialni komunikaciyi. Vyp. 1-2 (17-18). P. 154-158. [in Ukrainian].

DOI https://doi.org/10.51647/kelm.2020.3.2.9

НАЦІОНАЛЬНА ІДЕНТИЧНІСТЬ У ТВОРАХ І. ДРЯПАЧЕНКА

\author{
Тетяна Мячкова \\ аспірантка кафедри теорії та історії мистецтвва \\ Національної академії образотворчого мистецтвва і архітектури (Київ, Україна) \\ ORCID ID: 0000-0003-4315-2349
}

\begin{abstract}
Анотація. У статті грунтовно висвітлена національна складова частина мистецької спадщини українського живописця і графіка I. Дряпаченка та розкрита її цінність для історії українського образотворчого мистецтва першої третини XX ст. Уперше публікуються зображення портрету Я. Пономаренка (1931, приватна збірка, Україна) та картини «На гойдалці (Сільська розвага)» (1920, приватна збірка, РФ). Також вперше оприлюднюється прізвище жінки, зображеної в картині «Параска у святковий день» (1915, місцезнаходження невідоме).
\end{abstract}

Ключові слова: Іван Дряпаченко, живопис, українське мистецтво, портрет, пейзаж, жанрові сцени.

\title{
NATIONAL IDENTITY IN I. DRIAPACHENKO'S WORKS
}

\author{
Tatiana Miachkova \\ Postgraduate Student at the Department of Theory and History of Art \\ National Academy of Fine Arts and Architecture (Kyiv, Ukraine) \\ ORCID ID: 0000-0003-4315-2349
}

\begin{abstract}
The article confidently shows the national component of Ukrainian artist and graphic artist I. Driapachenko's artistic heritage, reveals the potential of it in the development of Ukrainian fine art of the first third of the XX century.
\end{abstract}


Images of works by I. Driapachenko "On a swing (Rural fun)" (1920, private collection, Russian Federation) and portrait of Y. Ponomarenko (1931, private collection, Ukraine) are published for the first time. The name of the woman depicted in the painting "Parasca on the Holiday Day" (1915, location unknown) is published for the first time.

Key words: Ivan Driapachenko, painting, Ukrainian fine art, portrait, landscape, genre.

\title{
TOŻSAMOŚĆ NARODOWA W PRACACH I. DRIAPACZENKI
}

\author{
Tetiana Miachkova \\ aspirantka Wydziatu Teorii i Historii Sztuki \\ Narodowej Akademii Sztuk Pięknych i Architektury (Kijów, Ukraina) \\ ORCID ID: 0000-0003-4315-2349
}

Adnotacja. Artykuł dokładnie podkreśla narodowy składnik dziedzictwa artystycznego ukraińskiego malarza i grafika I. Driapaczenki i ujawniono jego wartość dla historii ukraińskiej sztuki wizualnej pierwszej trzeciej XX wieku. Po raz pierwszy publikowane sa obraz portretu Y. Ponomarenki (1931, kolekcja prywatna, Ukraina) i obraz, Na huśtawce (Wiejska rozrywka)" (1920, kolekcja prywatna, Federacja Rosyjska). Po raz pierwszy ogłoszono także nazwisko kobiety przedstawionej w obrazie „Paraska w święto” (1915, położenie nieznane).

Słowa kluczowe: Iwan Driapaczenk, malarstwo, sztuka ukraińska, portret, pejzaż, sceny rodzajowe.

Вступ. Творчість живописця і графіка першої третини XX ст. I. Дряпаченка не була об'єктом поглиблених досліджень у царині радянського та українського мистецтвознавства. Тому вивчення живописних і графічних робіт I. Дряпаченка, що несуть у собі національну ідею, збагатить історію української культури. У 2000-і рр. в України посилився інтерес до творчості митця. Тому введення в науковий обіг раніше невідомих творів I. Дряпаченка стане важливим джерелом інформації. Метою статті є вперше виявити структурно-образні і художньо-стильові особливості творів І. Дряпаченка народної тематики, окреслити значення творчості майстра в контексті розвитку українського образотворчого мистецтва першої третини ХХ ст.

Основна частина. Завдання полягає в комплексному дослідженні творів I. Дряпаченка народної тематики різних за жанрами, стилем, техніками і часом виконання, застосовуючи такі загальнонаукові методи, як мистецтвознавчий аналіз, систематизація, узагальнення та запропонований візуальний ряд, продемонструвати національну ідентичність у творах майстра. Матеріалами для дослідження є живописні і графічні твори I. Дряпаченка побутового, пейзажного, портретного жанрів та жанрові сцени, що зберігаються в музейних та приватних колекціях, документи Центрального державного архіву-музею літератури і мистецтва України (далі - ЦДАМЛМ України), дореволюційна періодика, поштові листівки. Питання національної ідентичності у творчості I. Дряпаченка частково порушувалося В. Рубан. Вона акцентувала увагу на розробці художником народної тематики здебільшого в портретному жанрі (Рубан, 1986: 164).

Результати. Акт самоідентифікації є засадничим моментом візуального мистецтва. Він розгортається в процесі емоційно-образного, духовно-чуттєвого переживання, шляхом відтворення соціального, етичного та естетичного досвіду особи через перенесення в образ. У парадигмі художньої творчості - «Мистецтво як мімезис», що грунтується на реалізмі зображення, відтворення дійсності доповнюється самовідтворенням митця (Личковах, 2011: 128). В. Личковах зазначає: «<..> в процесі художньої творчості художник-реаліст ідентифікує себе з образом, а втілення чи перевтілення зберігають етос особистості і самовідображення митця. У імпресіонізмі об'єктивно-позитивістський підхід зливається із суб'єктивізмом зору, естетичної рецепції загалом, а «відсторонене» сприйняття світу переростає в самоідентифікацію з ним» (Личковах, 2011: 129-130).

Досліджуючи творчість І. Дряпаченка (1881-1936) - талановитого, неординарного митця з бідної селянської родини, можна констатувати той факт, що його художня самоідентифікація не мала якихось обмежень, чи то стиль, жанр, чи то техніка виконання твору. Переважна частина мистецької спадщини І. Дряпаченка втрачена, але твори з музейних і приватних збірок, архівні, друковані та Інтернет-джерела дають змогу уявити розмаїття мистецького доробку майстра, що становить живопис, рисунки, друковану графіку. За сорок років активної творчої діяльності I. Дряпаченко розкрив свій талант в усіх жанрах. Він використовував різні техніки, працював на пленерах. Художня самоідентифікація І. Дряпаченка формувалася під впливом академічної школи живопису. Вчителями І. Дряпаченка були видатні живописці: М. Мурашко, М. Пимоненко, В. Сєров, І. Рєпін. На початку 1910-х рр. у Західній Свропі I. Дряпаченко знайомиться з новими на той час течіями у мистецтві. Це приводить до змін у «творчому почерку». I. Дряпаченко працював як у реалістичній живописній традиції, так і в стилі імпресіонізму. Також він робив ікони для оздоблення сільських церков Полтавщини та домашні ікони (Ніколаєва, 2013: 145-154).

В України наприкінці XIX - початку XX ст. гостро постала проблема національної ідентичності. У мистецтві це проявилося через формування так званого українського стилю. Активне звернення українських митців до народних сюжетів було одним із проявів цих процесів. Прикладами можуть слугувати твори сучасників I. Дряпаченка - портрети та жанрові роботи у стилі модерн М. Жука, поетичні пейзажі Г. Світлицького (з I. Дряпаченком обох об’єднує навчання у Київській рисувальній школі) або батальні сцени у виконанні художників-реалістів М. Самокиша і К. Трохименка. Під час Першої світової війни І. Дряпаченко, М. Самокиш і К. Трохименко служили у військово-художньому загоні Трофейної комісії. А з К. Трохименком І. Дряпаченко ще й навчався в Московському училищі живопису, скульптури та архітектури і Вищому художньому училищі при Петербурзькій Академії мистецтв (Ніколаєва, 2013: 146, 150). 
Однак у творчості І. Дряпаченка національні мотиви не є панівними. Це стосується робіт майстра кінця XIX ст. - початку XX ст. Тому що він майже двадцять років провів у Москві та Петербурзі, отримуючи художню освіту, а у 1916-1917 рр. служив в армії. Але здебільшого проблематика дослідження творчості художника полягає в численних втратах його творів. Історичні і біографічні події 1906-1959 рр. негативно вплинули на стан збереження мистецької спадщини I. Дряпаченка. Так, живопис і графіка першого (академічного: кінець ХІХ ст. - 1911 р.) і четвертого (радянського: 1918-1936) періодів частково відомі лише за назвами або описом. Зокрема, відсутні зображення і невідоме місце знаходження ікон і натюрмортів. Майже така сама доля спіткала твори художника історичного та міфологічного жанрів. Водночас побутові та інтер'єрні роботи, пейзажі, портрети і твори з батальними сценами Першої світової війни є окрасою музейних збірок України, Росії, Білорусії та зберігаються в приватних колекціях. Також їх можна побачити у періодиці, на дореволюційних поштових листівках, фотографіях.

У низці творів І. Дряпаченка простежується виразна домінанта відчуття приналежності художника до української нації, любов до Вітчизни та національна гордість. Ці риси яскраво виявилися, в першу чергу, в портретному жанрі. Так, В. Рубан наголошувала: «...його портретні твори, виразні й майстерні, помітні навіть серед праць відомих майстрів цього жанру своєрідною мовою, ліричною нотою і пошуками суто живописного вираження духовної самобутності героїв» (Рубан, 1986: 164). М. Безхутрий зазначав: «Чимало глибоких, психологічних і яскравих портретів створили в цей період (до 1917 р. - T.М.) П. Мартинович, О. Мурашко, І. Труш, І. Дряпаченко, К. Костанді» (Безхутрий, 1954: 19).

Так, у дореволюційному живописі митець неодноразово звертався до народної тематики. Мешкаючи в 1914-1915 рр. у рідному селі Василівка (Полтавська губ., Кременчуцький пов.), І. Дряпаченко відображував на полотнах образи родичів та односельців, зокрема Параски Бордюг (Терещенко, 1966-1981: 60). Картина має назву «Параска у святковий день» (Рис. 1). П. Бордюг позувала майстру в хаті. Вона сидить за столом так наче тільки озирнулася і уважно слухає художника. Ї̈̈ корпус дещо нахилений уперед, тому в композиції відчувається певна динаміка. Інтер'єр хати наповнений цікавими дрібницями 3 побуту сільських жителів початку XX ст. В. Рубан наголошувала: «3 повагою і щирим почуттям малює художник зібрану і пластичну постать, довірливий погляд, свіже вродливе обличчя, звичайний жест гарних міцних рук. Дівчина у квітчастому вбранні, на голові вінок із ромашок. Та барвисте вбрання не відволікає погляду від обличчя, а навпаки ще відчутніше конкретизує на ньому увагу. I вже в цьому полягає неабияка обдарованість митця $<\ldots>$ У цьому образі повно відбилася одна з провідних тенденцій прогресивного мистецтва - його глибока демократичність» (Рубан, 1986: 167). 3 думкою В. Рубан безперечно можна погодитися. Портрети П. Бордюг (1915, місце знаходження невідоме), М. Горбань (1931, приватна збірка, Україна), Г. Миргородської (1934, Полтавський художній музей) не тільки підкреслюють красу та енергійність жінок, а уособлюють національні риси характеру українок.

Також підтвердженням думки В. Рубан, що «Благородство, духовне багатство людини 3 народу - основний мотив народних образів І. Дряпаченка» (Рубан, 1986: 167), є погрудний портрет 1933 р. Я. Пономаренка. Репродукція портрету публікується уперше (Рис. 2). Я. Пономаренко - теж мешканець с. Василівка (нині Козельщинський р-н, Полтавської обл.), за фахом тесляр. На час виконання портрету він важко хворів. І. Дряпаченко, схвильований за свого друга, нашвидкуруч робить малюнок. Я. Пономаренко зображений анфас, волосся зачесане назад, ріденька борідка і вуса. Обличчя портретованого бліде, блакитні очі дещо запалені.

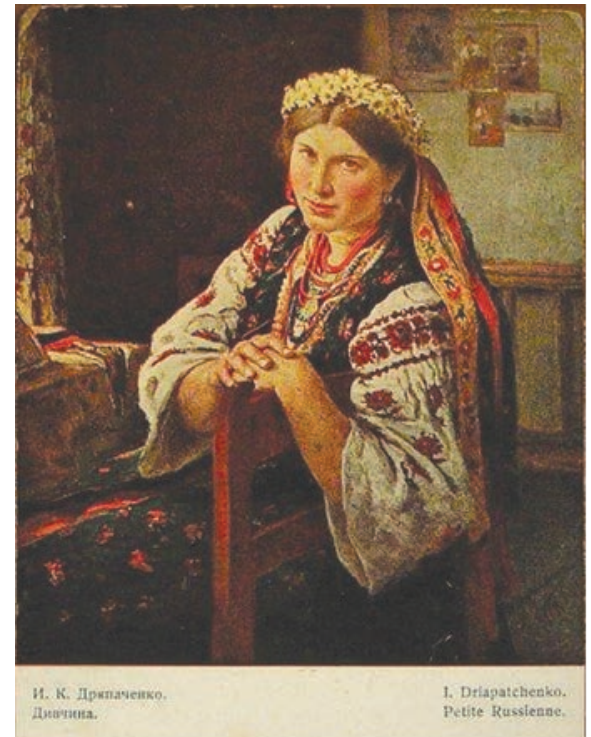

Рис. 1. І. Дряпаченко. 1915. Параска у святковий день. П., о. Місце знаходження невідоме

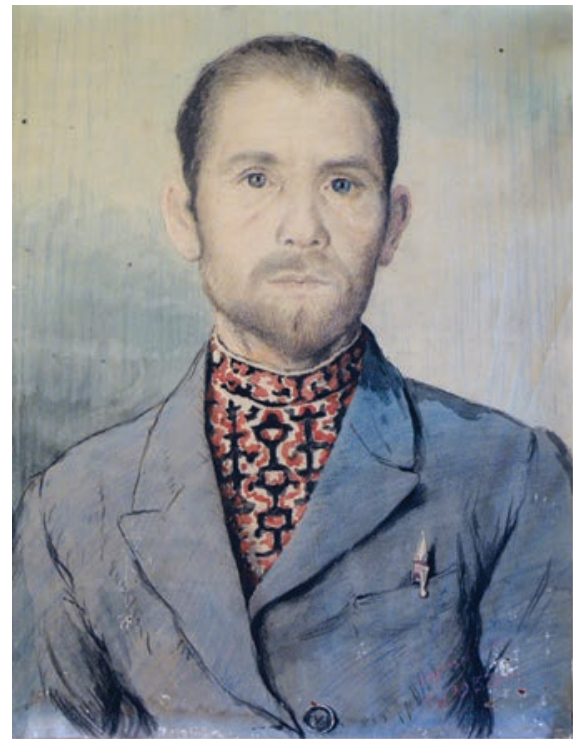

Рис. 2. І. Дряпаченко. Портрет

Я. Пономаренка. Папір, акварель, о. 33x42. 1933. Приватна збірка

Я. Пономаренко одягнутий у вишиванку та простенький синього кольору піджак, із нагрудної кишені якого виглядає чорнильна ручка. Вірогідно, рисунок створено в один сеанс, тому тло нерозроблене.

У цьому творі I. Дряпаченко продемонстрував свій талант рисувальника та навички швидко працювати. Навички, яких він набув під час Першої світової війни, коли служив у складі воєнно-художнього загону Трофейної комісії. Художники загону мусили оперативно вихоплювати фронтові сюжети, нашвидкуруч робити портрети військових та замальовки 3 життя прифронтових міст і сіл. Зразком 
таких репортажних портретів є рисунок селянина під назвою «Типи Галіції», опублікований у журналі «Летопись войны 1914-15-16 гг.» за 1917 (№ 126, с. 2017) та інші портретні роботи воєнного періоду.

В. Рубан справедливо вказувала на те, що І. Дряпаченко не був виключно портретистом (Рубан, 1986: 164). Свідченням цієї тези є жанрові та побутові роботи I. Дряпаченка різних періодів творчості. Перебування на батьківщині приносило художнику не тільки задоволення зустрічі з рідними, але й збагачувало його творчу уяву новими сюжетами $з$ життя українського народу. Як приклад, можна навести живописне полотно «На озері (Вечір біля озера)» (рис. 3).

У висвітлені народних сцен I. Дряпаченко майстерно поєднував побутовий i пейзажний жанри. В. Рубан зазначала:

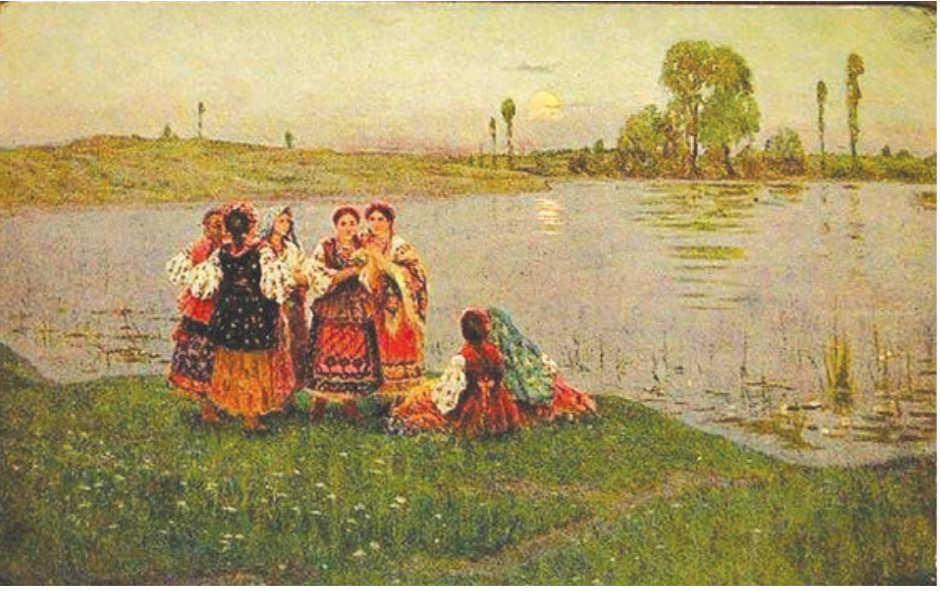

Рис. 3. І. Дряпаченко. На озері (Вечір біля озера). 1915. П., 0. 150x250. Місце знаходження невідоме «Він прагнув не просто зафіксувати спостережені сцени, а розкрити неповторну поезію, гармонію єднання людини і природи $<\ldots>$ художник милується чарівною мелодією літнього вечора, злагодженим ритмом руху дівочих постатей у барвистому одязі, вечірньою тишею, розлитою у високому небі, у тихій воді, що віддзеркалює високі дерева вдалечині і яскраві квіти латаття» (Рубан, 1986: 166). Знову можна погодитися з В. Рубан у тому, що ця картина несе в собі своєрідну поетику образного ряду, яка підказана I. Дряпаченку його власними переживаннями. Так само можна охарактеризувати живописне полотно І. Дряпаченка «Назустріч вечору», якому притаманні елементи імпресіонізму і модерну (рис. 4).

Чотири молоді василівчанки зображені по центру в повний зріст. Така композиційна побудова надає картині статики і монументальності. Але в їхніх позах можна помітити певний рух. Дівчата наче зупинилися на мить. Це відчувається за рахунок різнонаправлених поглядів та зображення фігур у різних ракурсах. Творчі пошуки привели І. Дряпаченка до поєднання в одній роботі одразу кількох жанрів. Надвечірній краєвид 3 озером, на тлі якого стоять українки, надає цій сцені сюжетності. Значну увагу художник приділяє етнографічним моментам у розробці жіночого національного вбрання Полтавщини. Пастозні мазки, якими художник написав одяг та вінки, контрастують із тонким прорисовуванням трави. Контраст головних кольорів - червоного і зеленого - надає яскравого колориту картині. Живописна манера твору «Назустріч вечору» (1915, ДОХМ) позбавлена академічної скутості, як і усі роботи майстра 1914-1915 рр., адже вони були виконані після повернення із Західної Свропи. Знайомство з імпресіоністичним баченням світу європейськими митцями вплинуло на подальшу творчість І. Дряпаченка.

У жанрових і побутових творах I. Дряпаченка перших десятиліть XX ст. помітний відголос передвижницької традиції. Як приклад можна навести, картину «Недільний день біля русинської церкви в с. Товстобаби» (1916, місце знаходження невідоме). Водночас його образотворення переживає наочні зміни - композиції стають більш динамічними, з'являються імпресіоністичні колористичні прийоми. Це загальна тенденція візуального мистецтва того часу, яка була притаманна цілій низці українських митців. Вплив імпресіонізму і пленеризм привели до трансформації жанрової системи, що спостерігається у творах О. Мурашка, П. Левченка, Ф. Кричевського та ін.

Після демобілізації у грудні 1917 р. і до смерті у грудні 1936 р. I. Дряпаченко постійно мешкав у с. Василівка. Жахливі часи Громадянської війни в Україні та важкі умови існування сільських мешканців не сприяли творчій праці. Людина, яка ще кілька років тому переживала злет своєї кар'єри в Петербурзі, мала власну майстерню, гарний заробіток - нині змушена якось добувати поживок, мешкаючи самотньо у хаті батьків. Так жив I. Дряпаченко останні десятиріччя. До того ж треба було якось пристосовуватися до нових радянських стандартів. Водночас рідна Полтавщина надихала I. Дряпаченка, як і раніше, на висвітлення життя своїх земляків. Жанрова сцена I. Дряпаченка 1920 р. «На гойдалці (Сільська розвага)» (рис. 5) відома завдяки архівній світлині (Терещенко, 1966-1981: 206).

В основі композиції трикутник. Він складається 3 вертикальних стовпів гойдалки та натовпу селян. Рух гойдалки надає сюжету динаміки. Розташування млинів праворуч і ліворуч від гойдалки

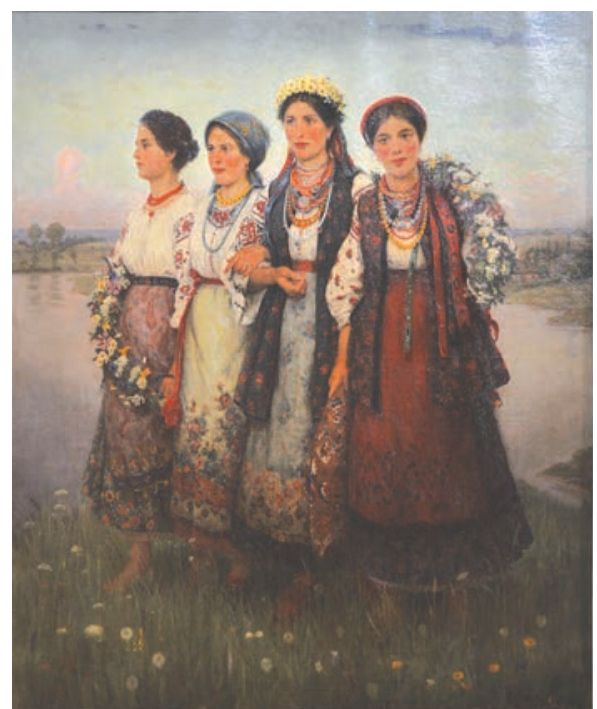

Рис. 4. І. Дряпаченко. Назустріч вечору. 1915. П., о. $203 \times 180$.

Донецький обласний художній музей 


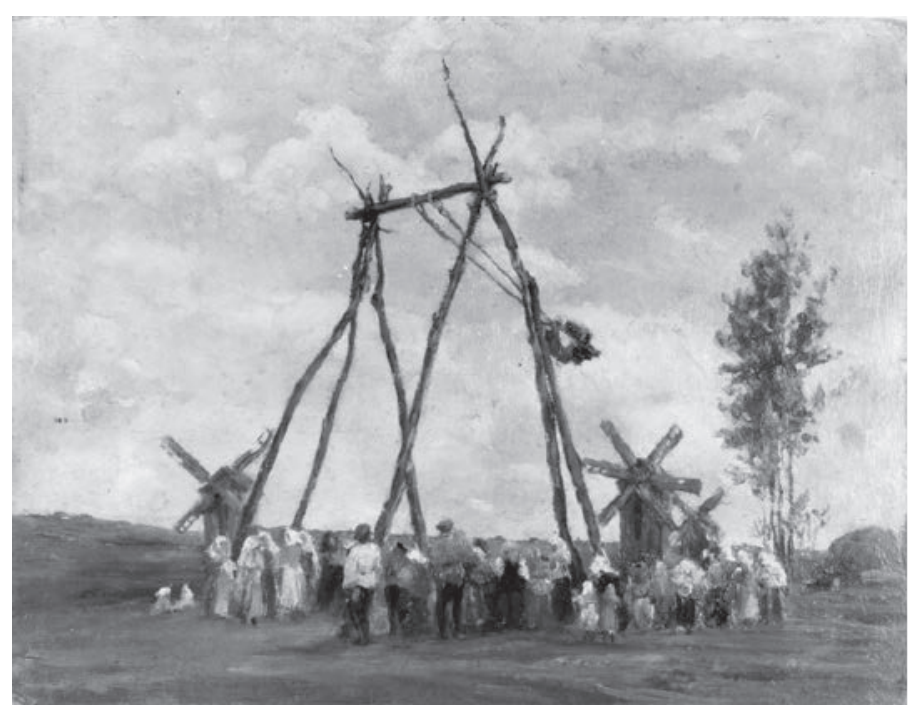

Рис. 5. І. Дряпаченко. На гойдалці (Сільська розвага). 1920. Картон, о. $21 \times 28$. Приватна збірка

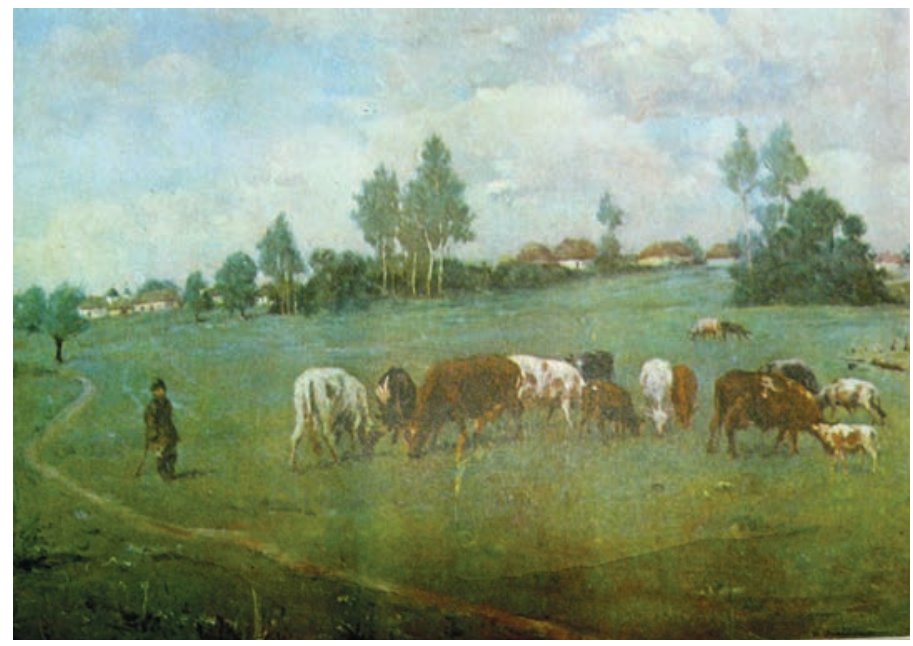

Рис. 6. І. Дряпаченко. Корови на лузі. Б/д. Картон, о. 21х28. Приватна збірка урівноважують композиційне рішення полотна, а пишне дерево праворуч оживляє одноманітність тла. Майже всі люди дивляться на гойдалку. Їхні маленькі фігурки позначені плямами. Розмір твору та манера письма свідчить про пленерний характер цієї роботи I. Дряпаченка.

До жанрових сцен та побутового жанру радянського періоду належать такі твори І. Дряпаченка, як «Ярмарок» (1918), «Жнива» (1920), «3 косовиці додому» (1920). Місце знаходження їх невідоме і відсутні зображення (Терещенко, 1966-1981: 102-103). У контексті дослідження побутового жанру у творчості І. Дряпаченка варта уваги живописна робота «Корови на лузі» (б/д, приватна збірка, РФ) (рис. 6).

3 ніжністю та любов'ю до рідного краю створив художник цей твір. Конструктивна простота та лаконічність центричної композиції підкреслює буденність сільського життя - череда корів пасеться на лузі під наглядом пастуха. Завдяки високій лінії горизонту соковита зелена трава заповнює дві третини полотна, а одна третина віддана блакитному небу 3 купчастими хмарами. На обрії низка зелених дерев і хати. Датування твору I. Дряпаченка «Корови на лузі» невідоме, а про техніку виконання і розміри можна дізнатися 3 архівних документів (Виписки, 1898-1919: 6).

Роботи I. Дряпаченка різних періодів творчості є зразком вдалого втілення національних мотивів у живописі та графіці. Учень та біограф I. Дряпаченка художник-пейзажист А. Терещенко (1900-1991) вважав, що майстер у своєму мистецтві наслідував традиції М. Пимоненка, К. Костанді, С. Васильківського (Ніколаєва, 2013: 151).

Аналізуючи внесок українських пейзажистів у розвиток вітчизняного образотворчого мистецтва першої третини XX ст., М. Безхутрий звертав увагу на поєднання жанрів в їхніх творах: «Нерозривну єдність жанру і пейзажу становлять собою багато творів М. Пимоненка, К. Костанді, І. Селезньова, Ф. Красицького, I. Дряпаченка та інших художників. Деякі з них є прекрасними зразками пейзажного мистецтва» (Безхутрий, 1954: 20). 3 цією тезою, безсумнівно, можна погодитися. У своїй творчості І. Дряпаченко звертався до мотивів як сільського, так і міського життя українців. Відомі його пейзажі воєнного періоду. Для них характерні пошуки лаконічних, так би мовити, репортажних композиційних рішень, розроблених на пленері. Пейзажні твори І. Дряпаченка «Тарнополь. Галіція» (1916, Державний історичний музей, Москва, РФ) (рис. 7) та «Галіція. Тоустобаби» (1916, місце знаходження невідоме) (рис. 8) опубліковані в журналі «Летопись войны 1914-15-16 гг.» за 1916 р. (№ 116, с. 1851 та № 117, с. 1867 відповідно).

Саме графічна робота «Галіція. Тоустобаби» може слугувати зразком такого репортажного малюнку. На ній художник зобразив, бачений у селі, зруйнований храм. У сюжеті міського пейзажу «Тарнополь. Галіція» теж домінує будівля церкви. Художник вдало вибрав ракурс, при якому храм розташований кутом до глядача. Добре видно архітектурне планування церковної споруди, а також у перспективі праворуч інші будівлі по вулиці. Створена кутом церкви вертикаль розділяє композицію на дві рівні частини, але ця прямолінійність згладжується завдяки затемненому куту будинка на передньому плані. У статті представлена чорно-біла ілюстрація з журналу, тому немає змоги розглянути колористичне вирішення твору. Однак чітка тінь від стіни будинку праворуч вказує на сонячний день у Тернополі, по тихій вулиці якого йдуть не поспішаючи люди. І. Дряпаченку вдалося органічно поєднати принципи пленеризму з пластичним моделюванням форми та передати спокій і тишу в місті, хоча в цей час йшла війна.

До радянського періоду належить пейзажна робота художника «Вечір на Україні» (рис. 9) зі збірки Полтавського художнього музею (галереї мистецтв) імені Миколи Ярошенка. Рік створення полотна свідчить 
про те, що І. Дряпаченко написав його у с. Василівка. Улюблені художником сутінки з’являються в низці жанрових та пейзажних творів І. Дряпаченка. Не є винятком і ця картина. Теплий літній вечір. На вулиці тиша, в хаті не світяться віконця. Все завмерло - журавель, тин, хата, дорога. Природа готується до відпочинку. У небі проблиски останніх променів сонця. Високе дерево позаду хати дещо затіняє сонячну заграву. Попри невеликий розмір картини художник скрупульозно розробив вечірнє небо. Ліричний пейзаж у виконанні І. Дряпаченка передає настрій передвечір'я в селі.

На думку В. Рубан, творчість І. Дряпаченка має важливе значення в розкритті тенденцій українського живопису напередодні Жовтня. Також вона вказувала на спад його потенціалу у наступні роки (Рубан, 1986 : 164, 213). 3 цими тезами важко погодитися. Доказом зворотного є наведене дослідження.

I. Дряпаченко пройшов складний шлях - зі звичайного сільського хлопця (чий батько ще в середині XIX ст. був кріпаком) до професійного майстра пензля. Працьовита, цілеспрямована, уперта людина, яка все життя шліфувала свій талант. На жаль, доля виявилася несприятливою до мистецької спадщини І. Дряпаченка. Після смерті художника у 1936 р. вона була розпродана, а те, що залишилось, було вивезене до Німеччини під час Другої світової війни (Терещенко, 1966-1981: 80).

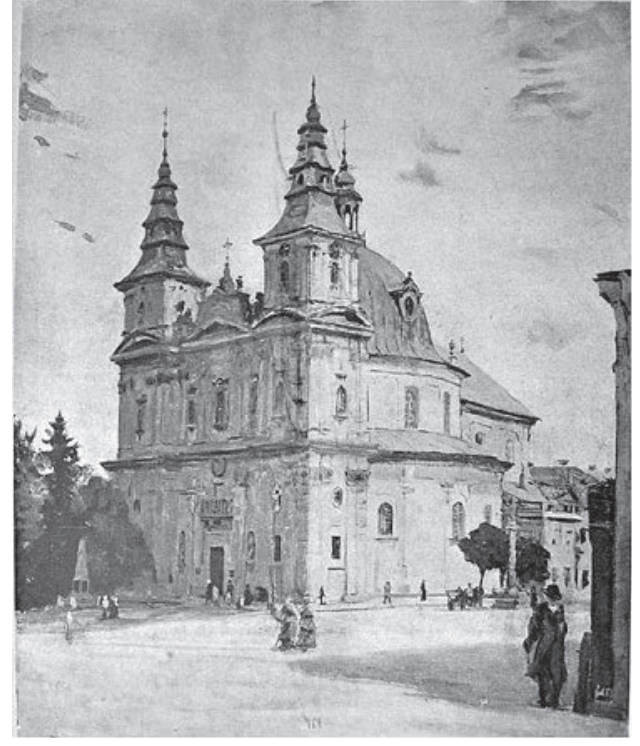

Рис. 7. І. Дряпаченко. Вид собору у місті Тарнополі (Тернополі) у Східній

Галиції. 1916. Полотно на картоні, о. 63x45. Державний історичний музей (Москва)

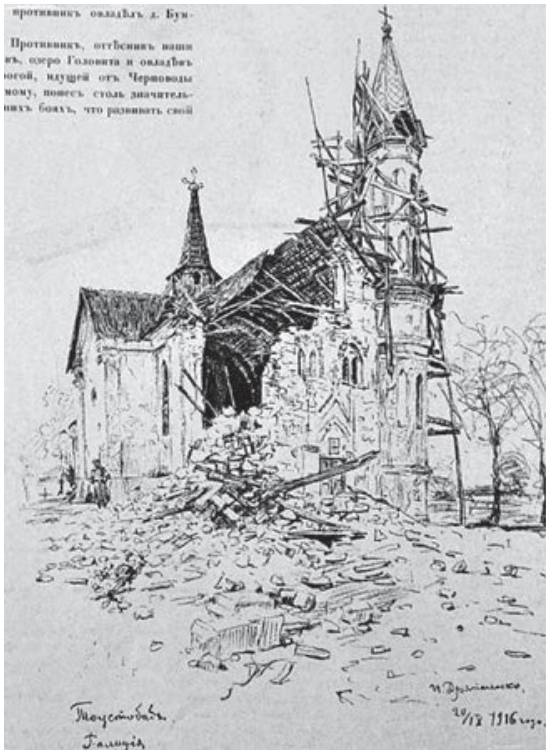

Рис. 8. І. Дряпаченко. Галіція. Тоустобаби. 1916.

Місце знаходження невідоме

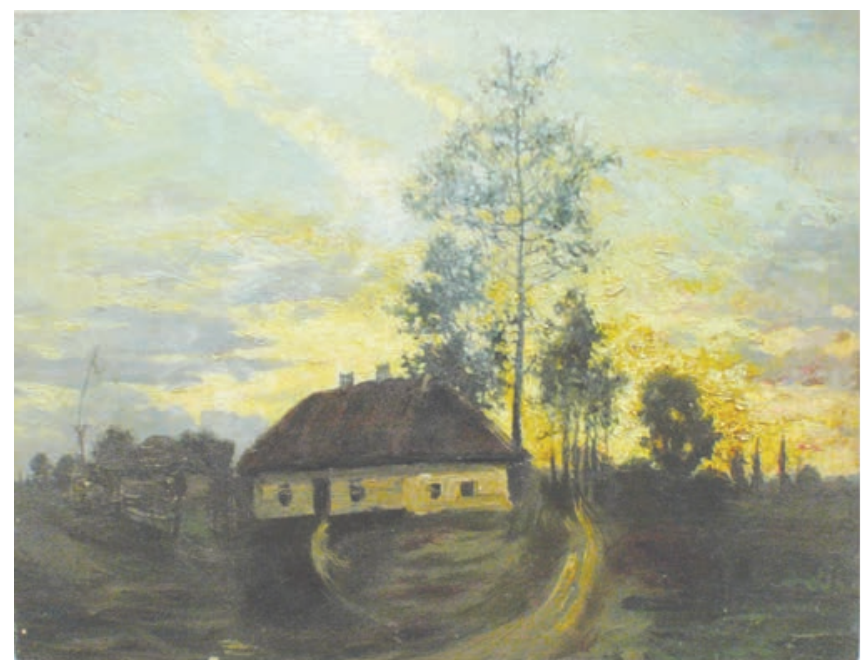

Рис. 9. І. Дряпаченко. Вечір на Україні. 1920. Картон, о. 21x27,5. Полтавський художній музей (галерея мистецтв) імені Миколи Ярошенка 
Висновки. Завдяки художній самоідентифікації майстра та неабиякому таланту мистецтво I. Дряпаченка вийшло за межі конкретних художніх чи історичних категорій. Мотиви українського народного життя, краєвиди Полтавщини і Галичини, портрети земляків свідчать про чітко виражену національну ідентичність і присутність національної ідеї у його творах. Адже «національні образи можна сприймати як своєрідні маркери, які відображають поняття національної ідентичності» (Лисак, 2011: 76). Ця ідея Н. Лисак цілком слушна в дослідженнях у царині образотворчого мистецтва. Отже, різні за стилем живописні і графічні роботи І. Дряпаченка побутового, пейзажного, портретного жанрів та твори 3 жанровими сценами наповнюють історію українського образотворчого мистецтва першої третини XX ст. цінним візуальним матеріалом. У перспективі подальших досліджень необхідно розкрити розмаїття змістовних та формально-стилістичних особливостей творів I. Дряпаченка всіх періодів творчості.

1. Безхутрий М.С. І. Васильківський. Київ : Мистецтво, 1954. 47 с.

2. Виписки з каталогів виставок. 1898-1919 рр. ЦДАМЛМ України, Ф. 1144, Оп. 1, Спр. 22, Арк. 13.

3. Лисак Н.С. Національна ідентичність та національні образи в літературі: розходження і точки дотику. Наукові праці Чорноморського державного університету імені Петра Могили. 2011. Вип. 156. С. 76-80.

4. Личковах В. Мистецька самоідентифікація у художній творчості. Наукові записки Нац. ун-ту «Острозька академія». 2011. Вип. 7. С. 127-134.

5. Ніколаєва Т. Повернення з небуття (архівні документи про українського художника І. Дряпаченка). Архіви України. 2013. № 4. С. 143-155.

6. Рубан В. Український портретний живопис другої половини XIX - початку XX століття. Київ: Наук. думка. 1986.219 с.

7. Терещенко А.К. «І. К. Дряпаченко». 1966-1981. ЦДАМЛМ України, Ф. 1144, Оп. 1, Спр.14., Арк. 215.

\title{
References:
}

1. Bezhutry M. (1954) Vasylkivsky S.I. [Vasylkivsky S.I.] K., Mystetztvo. P. 47. [in Ukrainian].

2. Vypyski z katalogiv vistavok (1898-1919) [The information from the catalogs of exhibitions for] TsDAMLM of Ukraine, F. 1144, L. 1, M. 22, P. 13. [in Ukrainian].

3. Lisak N.S. (2011) Natzionalna identichnist ta natzionalni obrazy v literaturi: rozhodgennia I tochki dotiky [National Identity and National Imagery in Literature: Differences and Points of Touch] Naukovi pratzi Chornomorskogo derdgavnogo universitetu imeni Petra Mogily. Vyp. 156. P. 76-80. [in Ukrainian].

4. Lichkoh V. (2011) Mystetzka samoidentifikatzia u hudodgny tvorchosti [Artistic Identification in Artistic Creativity]. Naukovi zapiski Natzionalnogo universitetu «Ostrozka academia». Vyp. 7. P. 127-134. [in Ukrainian].

5. Nikolaeva T. (2013) Povernenniy z nebuttia (arhivni document pro ukrainskogo hudodgnika I. Driypachenka) [Return from non-existence (The archival documents about the Ukrainian artist Driapachenko I.)]. Arhivy Ukrainy. Vyp. 4. P. $143-155$. [in Ukrainian].

6. Ruban V. (1986) Ukrainskiy portretniy dgivopis drugoi polovini XIX-pochatku XX stolittia [Ukrainian portrait painting of the second half of the nineteenth and early twentieth centuries]. K., Naukova dumka. P. 219. [in Ukrainian].

7. Tereschenko A. (1966-1981) Driapachenko I.K. [Driapachenko I.K.] TsDAMLM of Ukraine, F. 1144, L. 1, M. 14 , P. 215. [in Ukrainian].

DOI https://doi.org/10.51647/kelm.2020.3.2.10

\section{ПРИНЦИПИ МУЗИЧНОЇ ДРАМАТУРГІї У ФІЛЬМІ «ВОЛОДАР ПЕРСНІВ»}

\author{
Анастасія-Олена Пожарська \\ аспірант кафедри музикознавства та музичної освіти \\ Інституту мистеитв \\ Київського університету імені Бориса Грінченка (Київ, Украӥна) \\ ORCID ID: 0000-0002-9879-4771
}

\begin{abstract}
Анотація. У статті розглянуто принципові ознаки музичної драматургії фільму «Володаря Перснів». Під час вивчення кіномузики фільмів фентезі науковці переважно приділяють увагу стилістичним, гармонічним та мелодичним ознакам, лишаючи музичну драматургію поза увагою. Завданнями статті є виявлення типу і принципів музичної драматургії фільму «Володар Перснів». У процесі аналізу музичної драматургії був використаний метод комплексного аналізу кіномузики, запропонований Т. Шак, а також методи аналізу музичної драматургії з праць В. Бобровського, Т. Чернової, Л. Казанцевої, І. Соллертинського. В результаті досліджень було виявлено, що музична драматургія фільму «Володар Перснів» належить до епіко-драматичного контрастно-конфліктного сюжетно-монтажного романтичного симфонічного типу. У статті були сформовані основні принципи музичної драматургії «Володаря Перснів». По-перше, найбільш запам’ятовуваним є інтонаційно-синтаксичний рівень сприйняття. По-друге, музичні теми контрастують між собою та вступають у конфлікт. По-третє, музичний конфлікт має спрямування від мажору до мінору. По-четверте, теми мають музичний розвиток. По-п’яте, музичний
\end{abstract}

